\title{
How to Improve Safety Commitment: A Case Study on a Plastic Manufacturer in East Java
}

\author{
Cara Meningkatkan Safety Commitment: Studi Kasus Pada Produsen \\ Plastik di Jawa Timur
}

\author{
Suherdin $^{1}$, Noeroel Widajati ${ }^{2}$, M. Bagus Qomaruddin ${ }^{3}$ \\ ${ }^{1}$ Faculty of Health Sciences, Bhakti Kencana University \\ Soekarno-Hatta Street No. 754 Cibiru, Bandung, West Java 40614, Indonesia \\ ${ }^{2,3}$ Faculty of Public Health Universitas Airlangga \\ Campus C Mulyorejo, Surabaya, East Java 60115
}

\begin{abstract}
Introduction: Every year, work accidents frequently occur at PT. X. The initial survey showed a lack of control and commitment to be the main problems. Commitment is the core of the implementation of Occupational Health and Safety (OHS). This study aims to determine the factors that can increase safety commitment of workers. Method: This study used a quantitative approach with a cross-sectional design. In this study, the independent variables were age, gender, years of service, education level, safety motivation, management of safety commitment, safety communication, and social support. Meanwhile, the dependent variable was the safety commitment. 78 workers were selected using a simple random sampling technique from a population of 395 workers. Questionnaires were used to collect data. Data analysis used a multinomial logistic regression test. Results: $64.1 \%$ of workers were aged $41-51$ years old, $56.4 \%$ were females, $82.0 \%$ had $>10$ years of service, $75.6 \%$ had a secondary education level, $56.4 \%$ had high safety motivation, $57.7 \%$ assessed management commitment to safety as low, $59.0 \%$ assessed safety communication as less, $52.6 \%$ had high social support, and $37.2 \%$ tended to have continuous safety commitment. Characteristics of workers (age, gender, years of service, education level), safety motivation, and social support did not affect safety commitment. Meanwhile, management commitment to safety $(\mathrm{p}=0.004)$ and safety communication $(\mathrm{p}=0.014)$ affected safety commitment of workers. Conclusion: The way to increase workers' commitment to safety is to increase the company's commitment to OHS and improve safety communication efforts.
\end{abstract}

Keywords: management commitment to safety, safety commitment, safety communication

\section{ABSTRAK}

Pendahuluan: Setiap tahun selalu terjadi kecelakaan kerja di PT. X, survei awal menunjukkan rendahnya kontrol dan komitmen menjadi masalah utama. Komitmen merupakan inti dari penerapan Keselamatan dan Kesehatan Kerja (K3). Tujuan penelitian untuk mengetahui faktor yang dapat meningkatkan komitmen keselamatan pekerja. Metode: Pendekatan kuantitatif, dengan rancang bangun cross-sectional. Variabel independent yaitu usia, jenis kelamin, masa kerja, tingkat pendidikan, motivasi keselamatan, komitmen keselamatan manajemen, komunikasi keselamatan, dan dukungan social. Sedangkan variable dependen yaitu komitmen keselamatan pekerja. Sampel sebanyak 78 pekerja diambil dengan teknik simple random sampling dari populasi 395 pekerja. Instrumen penelitian yang digunakan adalah kuesioner. Analisis data menggunakan uji regresi logistik multinomial. Hasil: 64,1\% pekerja memeliki rentang usia 41-51 tahun, 56,4\% berjenis kelamin perempuan, 82,0\% memiliki masa kerja lebih dari 10 tahun, 75,6\% memiliki tingkat Pendidikan menengah, 56,4\% memiliki motivasi keselamatan tinggi, 57,7\% menilai komitmen manajemen terhadap keselamatan rendah, 59,0\% menilai komunikasi keselamatan di perusahaan kurang baik, 52,6\% mendapatkan dukungan sosial tinggi, dan 37,2\% memiliki kecenderungan terhadap komitmen keselamatan kontinyu. Karakteristik pekerja (usia, jenis kelamin, masa kerja, tingkat pendidikan), motivasi keselamatan, dan dukungan sosial tidak berpengaruh terhadap komitmen keselamatan. Sedangkan variabel komitmen keselamatan manajemen $(p=0,004)$ dan komunikasi keselamatan $(p=0,014)$ berpengaruh terhadap safety commitment pekerja. Simpulan: Cara untuk meningkatkan komitmen pekerja terhadap keselamatan adalah dengan meningkatkan komitmen perusahaan terhadap K3 dan meningkatkan upaya komunikasi keselamatan.

Kata kunci: komitmen keselamatan manajemen, komitmen keselamatan, komunikasi keselamatan

(C2021 IJOSH All right reserved. Open access under CC BY NC-SA license doi:10.20473/ijosh.v10i3.2021.289-298 Received June 28, 2021, received in revised form August 16, 2021, Accepted August 18, 2021, Published: December 2021 


\section{Corresponding Author:}

Noeroel Widajati

Email: noeroel2014@yahoo.co.id

Telephone: +6285730961962

\section{INTRODUCTION}

Occupational Health and Safety (OHS) is the main aspect that must be implemented by company management as a form of protection for the right to live healthily and safely for workers (Suherdin, Mulya and Kurniawati, 2019). The OHS implementation in the company's system and the provision of health and safety guarantees for workers can also guarantee the safety of the company's products and assets. However, this guarantee is not one hundred percent because in the theory of work accidents other factors other than human factors and work environment factors, cannot be avoided. The key to this guarantee is to continue to increase commitment and improve the company's system so that work accidents do not occur (Umamah, Denny and Kurniawan, 2015).

Commitment to implement OHS is similar to the energy that drives the wheels of the organization's OHS policy. Government Regulation Number 50 of 2012 concerning the Implementation of the Occupational Health and Safety Management System (OHSM), which is contained in one of the clauses, has required companies to demonstrate a commitment to the implementation of OHS. The company concerned has a high OHS risk and more than 100 employees (Regulation of the Government of the Republic of Indonesia, 2012).

Various factors are known to be the causes of work accidents, one of which is a low safety commitment. When it comes to commitment, so far, it has only focused on management. Management commitment to safety is essential as management commitment determines the success of the occupational health and safety program. However, although management commitment to safety in improving safety performance is critical, several factors cannot be ignored. The substantial success of safety performance starts with the organization, but it must be strongly supported by the results of the collective behavior of workers. This means that the personal safety commitment of workers can have a significant effect on safety behavior and work accidents (Ghasemi et al., 2018).

Regarding commitment to safety, Fruhen, Griffin and Andrei (2018) divide the commitment to safety into three dimensions, namely affective safety commitment, normative safety commitment, and continuance safety commitment. Affective safety commitment reflects the desire of workers to be part of and involved in safety efforts because of the emotional bond, understanding of common goals and involvement in the organization. Normative safety commitment means the awareness of workers that safety is a need that must be met and involvement in safety activities must be carried out. Meanwhile, continuous safety commitment considers the benefits and costs made by workers regarding involvement, participation and compliance with policies.

Personal safety commitment is a behavioral domain that becomes a variable mediator of the factors that shape the behavior itself (Bird and Germain, 1996). Mashi, Subramaniam and Johari (2018) research explains that increased commitment can lead to behavioral changes in the short and long term. Increased safety commitment can undoubtedly have a good impact on the behavior patterns of workers in implementing work safety.

Baldissonea et al. (2019) stated that the direct causes of work accidents are unsafe acts and unsafe conditions. The results of the study showed that 85 $96 \%$ of the causes of work accidents were workers' behavior that led to unsafe acts. Referring to the Antecedent-Behaviour-Consequence (ABC) model of Behavior developed by B. F. Skinner, behavior is triggered by a series of antecedent events. It is followed by consequences that can increase or decrease the likelihood that the behavior will be repeated. In this model, commitment plays a role in the form of covert behavior that can influence behavior. This means that the antecedents can influence or increase commitment and then impact behavior (Rahman and Dwiyanti, 2020).

According to Ghasemi et al. (2018), organizational factors and a supportive work environment can influence workers' safety behavior. The results showed that management safety commitment and social environment support positively impacted safety commitment of workers. Social support can be provided in the form of emotional, reward, instrumental, information, and social network (Sarafino and Smith, 2017).

In general, the commitment will be high if someone has a specific motive and work safety commitment. According to Basahel (2021), the critical variable that influences safety participation and compliance is safety motivation. This is confirmed by the findings in the study of Mariani (Mariani, Soldà and Curcuruto, 2015), suggesting 
that motivation had the potential to increase safety commitment. The theory of motivation most relevant to the concept of work safety is the Self Determination Theory (SDT) developed by Ryan and Deci (Gunasekare, 2016).

Effective communication related to safety is vital to maintain a positive culture and involve workers in safety activities (Lyu et al., 2018). According to Chen et al. (2018), safety communication affects behavior and has a practical impact on the organizational safety performance, which means that safety communication can affect safety commitment of workers.

The purpose of this research is to find out what factors can increase safety commitment of workers. It is hoped that knowing these factors can provide input for suggestions in improving OHS implementation to increase safety commitment and safety behavior of workers.

\section{METHODS}

This research was conducted at PT X which is located in Sidoarjo City, East Java, Indonesia. The preliminary study at PT. X showed the number of work accidents in the last three years. In 2016 there were 105 work accidents, in 2017 there were 106 work accidents, and in 2018 there were 97 work accidents in 2018. From a total of 97 work accident cases at PT. X, $42.2 \%$ of them or 41 cases occurred in Division Y.

This study used a quantitative approach. Based on the aspect of data collection, the type of research used was analytical survey research, while based on the time the research was conducted, the research design was cross-sectional. The dependent variable in this study was safety commitment, and other variables were independent variables. Simple random sampling technique was used to take 78 samples from the total population of 395 workers in the Division Y. Simple random sampling was based on a list of workers' names using a random number generator.

The instrument used was a questionnaire with a Likert scale modified from previous research and relevant theoretical indicators. A safety motivation questionnaire modified from self-determination theory (Ryan and Deci, 2002), a management safety commitment questionnaire modified from Copper's indicators (Cooper, 2001), a safety communication questionnaire modified from Haslinda (Haslinda et al., 2016), and a social support questionnaire modified from Sarafino's social support indicators (Sarafino and Smith, 2017) were used in this study. A multinomial logistic regression test was further used to analyze the effect between variables simultaneously.

Each questionnaire had favorable and unfavorable statement items with a Likert scale ranging from 1 to 4 . The categorization of variables used the interval formula $(I=R / K)$, where $R$ is the range (maximum value - minimum value), and $\mathrm{K}$ is the category. This study divided the variables of safety motivation, management safety commitment, safety communication, and social support into two categories, based on the consideration of relevant previous research. Safety commitment was categorized based on the respondents' highest score on the dimension of safety commitment. This research has passed the ethical test from Airlangga University with certificate number 751/HRECC. FODM/XI/2019.

\section{RESULTS}

PT. $X$ is a manufacturing company in the field of plastic bags. The work process starts from raw materials to finished materials. The implementation of OHS in the company has not been maximized, as can be seen from the high number of accidents.

Table 1. Distribution of Workers' Characteristics in the Division Y of PT. X

\begin{tabular}{|c|c|c|c|}
\hline Variable & Category & $\mathbf{n}$ & $\%$ \\
\hline \multirow{4}{*}{ Age } & $\begin{array}{l}19-29 \text { years } \\
\text { old }\end{array}$ & 9 & 11.5 \\
\hline & $\begin{array}{l}30-40 \text { years } \\
\text { old }\end{array}$ & 19 & 24.4 \\
\hline & $\begin{array}{l}41-51 \text { years } \\
\text { old }\end{array}$ & 50 & 64.1 \\
\hline & Total & 78 & 100 \\
\hline \multirow{3}{*}{ Gender } & Male & 34 & 43.6 \\
\hline & Female & 44 & 56.4 \\
\hline & Total & 78 & 100 \\
\hline \multirow{4}{*}{$\begin{array}{l}\text { Years of } \\
\text { service }\end{array}$} & $<6$ years & 12 & 15.4 \\
\hline & $6-10$ years & 2 & 2.6 \\
\hline & $>10$ years & 64 & 82.0 \\
\hline & Total & 78 & 100 \\
\hline \multirow{4}{*}{$\begin{array}{l}\text { Education } \\
\text { Level }\end{array}$} & Elementary & 14 & 18.0 \\
\hline & Secondary & 59 & 75.6 \\
\hline & High School & 5 & 6.4 \\
\hline & Total & 78 & 100 \\
\hline
\end{tabular}


Table 1 shows that the majority (64.1\%) of workers were aged 41-51 years. The age of the workers is an essential factor in determining safety commitment and behavior. The older a person is, the less likely he will get another job opportunity when he leaves the company. This will increase commitment to the company. Furthermore, young people have better physical abilities than older people, while older workers have better thinking and responsibilities than young people, affecting workers' safety behavior.

Based on Table 1, it can be seen that most (56.4\%) workers at PT. X were females. Division $\mathrm{Y}$ has several production units, one of which is jumbo sewing, where almost all workers are females. Therefore, most of the respondents in this study were also primarily females.

Years of service were divided into three categories, namely new years of service ( $<6$ years), medium years of service (6-10 years), and long years of service ( $>10$ years). Table 1 shows that the majority $(82.0 \%)$ of workers had years of service of $>10$ years. The years of service are closely related to the experience gained, where the more experienced a worker is, the more he seems to understand the work and the potential hazards in his work environment they have.

Table 2. Distribution of Safety Motivation, Management Commitment to Safety, Safety Communication, Social Support, and Safety Commitment of Employees at PT. X

\begin{tabular}{llll}
\hline \multicolumn{1}{c}{ Variable } & \multicolumn{1}{c}{ Category } & n & \% \\
\hline \multirow{4}{*}{ Safety Motivation } & Low & 34 & 43.6 \\
& High & 44 & 56.4 \\
\cline { 2 - 4 } & Total & 78 & 100 \\
\hline \multirow{2}{*}{$\begin{array}{l}\text { Comagement } \\
\text { Safety }\end{array}$} & Low & 45 & 57.7 \\
\hline \multirow{3}{*}{ Safety } & High & 33 & 42.3 \\
\cline { 2 - 4 } Communication & Total & 78 & 100 \\
\hline \multirow{3}{*}{ Social Support } & Less & 46 & 59.0 \\
& Good & 32 & 41.0 \\
\cline { 2 - 4 } & Total & 78 & 100 \\
\hline \multirow{4}{*}{ Safety Commitment } & Low & 37 & 47.4 \\
\cline { 2 - 4 } & High & 41 & 52.6 \\
\cline { 2 - 4 } & Total & 78 & 100 \\
\cline { 2 - 4 } & Continuance & 29 & 34.6 \\
\cline { 2 - 4 } & Total & 78 & 100 \\
\hline
\end{tabular}

The categorization of the level of education in this study refers to the National Education System. Table 1 shows that most (75.6\%) workers at PT. X had a secondary education level. Education can affect a person's way of thinking about his work, including how to prevent and avoid work accidents.

Table 2 shows that most (56.4\%) workers had high motivation to behave in safety. This means that workers had a solid reason for behaving safely in the workplace environment. Management commitment to safety was measured based on workers' assessment of management's efforts to prioritize worker safety and organize work safety activities or programs in the company. Table 2 shows that most (57.7\%) workers assessed that management commitment to workplace safety was still low, meaning that the company's management had not made work safety a priority.

Most (59.0\%) of the workers assessed that the company's safety communication was still lacking. This means that the company's leadership had not provided directives regarding work safety properly, the company had not responded to worker complaints related to work safety, and safety communication media had not been adequately provided.

Social support is the presence of other people who can be relied on to provide help, encouragement, and attention. Table 2 shows that more than half of the total percentage $(52.6 \%$ of workers) got high social support. This means that workers felt they received help, enthusiasm, and great attention regarding safety behavior. Social support could come from colleagues and superiors.

Safety commitment in this study was the tendency of a strong determination and effort from workers to achieve safety goals and to behave safely at work. Table 2 shows that the tendency of the work safety commitment of Division Y workers

Table 3. Multinomial Logistics Regression Test of Candidate Variables

\begin{tabular}{lcl}
\hline \multicolumn{1}{c}{ Variable } & P-Value & Description \\
\hline Age & 0.153 & Candidate \\
Gender & 0.933 & Not Candidate \\
Years of Service & 0.683 & Not Candidate \\
Education Level & 0.734 & Not Candidate \\
Safety Motivation & 0.014 & Candidate \\
$\begin{array}{l}\text { Management Commitment } \\
\text { to Safety }\end{array}$ & 0.001 & Candidate \\
Safety Communication & 0.003 & Candidate \\
Social Support & 0.931 & Not Candidate \\
\hline
\end{tabular}


was primarily on continuance commitment to safety as many as 29 workers (37.2\%), while affective commitment to safety as accounted for 27 workers (34.6\%), followed by 22 workers $(28.2 \%)$ having a normative commitment to safety. This means that workers were more likely to have a safety commitment based on transactional considerations of profit and loss on safety behavior in the workplace.

There is no level of safety commitment dimension. However, a person's tendency towards one of the dimensions of safety commitment describes his condition and confidence in work safety. A person can have a determination based on closeness, beliefs, and transactional considerations.

\section{Analysis of Variables that Affect Safety Commitment}

A bivariable (partial) analysis was performed in this section before analyzing the effect of using a multinomial logistic regression test. The purpose of the partial analysis was to determine the candidate variables for the regression test. Based on the results of the chi-square test, several candidate variables were obtained table 3 . Based on the partial analysis, the candidate variables for the multinomial logistic regression test ( $p$-value $<0.25$ ) were age, safety motivation, management commitment to safety, and safety communication.

Based on Table 4, the variables that significantly affected safety commitment were management safety commitment and safety communication. Management safety commitment (low) had a positive $\mathrm{B}$ value for normative commitment and continuance commitment, meaning that the more workers rated management commitment to work safety as low, the higher the normative commitment and continuance commitment to safety would be. Safety communication (less) had a positive B value on continuance commitment, meaning that the more

Table 4. Multinomial Logistics Regression Test Results for the Effect of Age, Safety Motivation, Management Commitment to Safety, and Safety Communication, on Safety Commitment

\begin{tabular}{|c|c|c|c|c|}
\hline Safety Commitment & Independent Variable & P-Value & $\mathbf{B}$ & Description \\
\hline \multirow{13}{*}{ Normative } & Age & & & \multirow{4}{*}{ Not Significant } \\
\hline & 19 - 29 years old & 0.584 & -0.504 & \\
\hline & 30 - 40 years old & 0.146 & -1.266 & \\
\hline & $41-51$ years old & Reference & & \\
\hline & Safety Motivation & & & \multirow{3}{*}{ Not Significant } \\
\hline & Low & 0.290 & 0.729 & \\
\hline & High & Reference & & \\
\hline & Management Safety Commitment & & & \multirow{3}{*}{ Significant } \\
\hline & Low & 0.013 & 1.714 & \\
\hline & High & Reference & & \\
\hline & Safety Communication & & & \multirow{3}{*}{ Not Significant } \\
\hline & Less & 0.132 & 1.049 & \\
\hline & Good & Reference & & \\
\hline \multirow{13}{*}{ Continuance } & Age & & & \multirow{4}{*}{ Not Significant } \\
\hline & 19 - 29 years old & 0.092 & -2.124 & \\
\hline & $30-40$ years old & 0.790 & -0.199 & \\
\hline & $41-51$ years old & Reference & & \\
\hline & Safety Motivation & & & \multirow{3}{*}{ Not Significant } \\
\hline & Low & 0.058 & -1.384 & \\
\hline & High & Reference & & \\
\hline & Management Safety Commitment & & & \multirow{3}{*}{ Significant } \\
\hline & Low & 0.004 & 1.994 & \\
\hline & High & Reference & & \\
\hline & Safety Communication & & & \multirow{3}{*}{ Significant } \\
\hline & Less & 0.014 & 1.696 & \\
\hline & Good & Reference & & \\
\hline
\end{tabular}


workers rated the company's safety communication as low, the higher the workers' continuance commitment to safety would be.

\section{DISCUSSION}

\section{The Effect of Workers' Characteristics on Safety Commitment}

\section{Age}

Age is one determinant of maturity in thinking and working (Rachmawati and Paskarini, 2021). According to Jabri and Ghazzawi (2019), age is one of the individual characteristics that positively influences one's commitment and behavior.

The analysis of the effect of age on the safety commitment of Division Y workers at PT. $X$ showed that age had no significant effect on ' safety commitment of workers. Meanwhile, research conducted by Hayat et al., (2020) concluded that age had a significant effect on worker commitment.

In this study, workers in the age category of 4151 years old were more likely to have a continuance commitment to work safety. This means that workers were committed to working safely based on profit and loss considerations and felt the need to behave safely. This condition indicated that workers were less involved in safety programs and did not get what was expected regarding work safety which came from the organization, such as personal protective equipment. This has caused workers to have no affective commitment and no normative commitment to work safety.

\section{Gender}

The effect of gender on worker commitment is described in the study by Yusuf and Syarif (2018) suggesting that female workers tended to have a higher commitment than male workers did. This is because, in general, female workers face more significant challenges in their career development than male workers do. This is supported by Messner (2017) who stated that females' commitment was higher than that of males. This suggests that female workers tend to have a higher commitment than male workers do. Commitment to the organization in the concept of safety commitment leads to affective commitment to safety, where efforts the organization does, such as involving workers in planning OHS programs, involving workers in the development of OHS policies, and socializing work safety goals to workers, will foster an emotional bond between workers and the organization.

In this study, statistically, gender did not affect the safety commitment of workers. Based on the results of research at PT. X, the absence of gender influence on safety commitment can be caused by the company's lack of effort in providing socialization of the goals and benefits of work safety, and the company had not involved many workers in discussions about workplace safety. This causes the distribution of safety commitment of workers based on gender to be average in all categories of safety commitment. The results of this study are in line with research conducted by Hayat et al., (2020), who concluded that gender had no significant effect on worker commitment.

\section{Year of Service}

Year of service is a specific period or the length of time a person works in an organization (Suherdin et al., 2019). Year of service is one of the individual characteristics that affect employee commitment. The longer an employee works in an organization, the more it gives him the opportunity to accept more challenging tasks, greater autonomy, freedom of work, higher levels of extrinsic rewards, and the opportunity to occupy a higher position or position so that workers will be encouraged and put in extra effort to follow all company policies including work safety (Yusuf and Syarif, 2018).

In this study, statistically, the length of service did not significantly affect safety commitment. The results of this study are different from the results of research conducted by Siregar (2020), which concluded that years of service were not related to work commitment. PT. X had not implemented OHS properly, so the years of service did not affect safety experience and safety commitment.

\section{Education Level}

Education is a necessary process needed to get balance and perfection in the development of individuals and society. Education is also an activity with aims and objectives directed at building the potential of human beings (Sujana, 2019). According to National Education System, the education level is an educational stage determined based on students' level of development, goals to be achieved, and abilities developed (Republic of Indonesia, 2003). Education for workers helps them master theories and skills relevant to their work. 
Education level has a slight negative correlation with worker commitment. The higher the level of education a person has, the higher the expectations he has. Thus, it is impossible for the organization to fulfill all the expectations, leading to lower commitment of workers to the organization. (Yusuf and Syarif, 2018).

In this study, statistically, the level of education did not significantly affect safety commitment. This is not in line with research of Hayat et al. (2020), concluding that education significantly affected worker commitment. Based on the results of the study at PT. X, the absence of influence of education level on safety commitment in this study could be caused by the high homogeneity of the education level of workers, where almost all workers had a secondary education level.

\section{The Effect of Safety Motivation on Safety Commitment}

According to Basahel (2021), motivation means generating motives, generating the power of motion, or moving someone or oneself to do something to achieve satisfaction or goals. Motivation makes a person have more enthusiasm in doing something. According to Bytyqi (2020), several factors affected a person's commitment, one of which was motivation.

Based on the results of this study, most of the workers of Division Y at PT. X had a high safety motivation. It can also be seen that workers with high safety motivation were more likely to have a continuance commitment to work safety. This means that workers with high safety motivation have strong reasons to comply and participate in workplace safety based on transactional considerations. These considerations can be in the form of benefits obtained in safety if workers comply with safety rules.

This study statistically showed that safety motivation had no significant effect on safety commitment of workers. The results of this study contradict the research conducted by Al-Madi et al. (2017) whose research concluded that motivational factors had a significant effect on worker commitment. Based on conditions in the field, other factors that made safety motivation not affect safety commitment were the fact that the company had not made maximum efforts in conveying work safety goals, and there were no programs that could encourage workers to increase safety commitment, for example, awarding employees' contributions or achievements.

\section{The Effect of Management Commitment to Safety on Safety Commitment}

Commitment is an intention or determination to do something (Suárez-Albanchez et al., 2021). Commitment is at the core of the successful implementation of the OHS program in a company. Management commitment to OHS must be clearly demonstrated in daily activities and attitudes in every organizational policy. Management must support the success of OHS by showing a commitment that can be seen and felt by all lines in the organization. According to Ghasemi et al. (2018), one of the factors that can promote safety commitment of workers was management commitment to the implementation of OHS.

The results show that most of the workers assessed that management commitment to safety was still low. In the cross-tabulation results, it is shown that workers who assesses that management commitment to safety was low tended to have continuance commitment to safety. This means that workers realized that management had not prioritized work safety in the company. This has caused workers to behave safely based on internal considerations and based on the potential gains or losses obtained from a safety perspective. The crosstabulation results also show that workers who rated high for management commitment to safety tended to have an affective commitment to safety. This means that workers who assessed that the company prioritized safety tended to have the same goals and emotional bonds with company leaders to have an effective commitment to safety.

This study statistically showed that management commitment to safety had a significant effect on safety commitment of workers. This is in line with Ghasemi et al. (2018), concluding that management commitment affected safety commitment. This shows that workers can perceive management commitment as a form of the company's seriousness in implementing the OHS program so that workers feel the need to make efforts to run and participate in the OHS program. On the other hand, low management commitment can be seen as the company's lack of seriousness in implementing OHS policies.

In this section, it can be explained that companies need to develop OHS policies and implement OHS according to its primary standards to increase safety commitment of workers, showing the company's seriousness in implementing OHS. This can be done by providing all logistics, instruments, and resources related to OHS. 


\section{The Effect of Safety Communication on Safety Commitment}

Recently, the importance of safety communication has become a topic of much attention (Abdullah and Aziz, 2021). According to Pandit et al. (2018), effective safety communication in the work environment is critical. This is in line with Lyu et al. (2018) which revealed that safety communication had a significant positive relationship with safety participation, which was a domain of commitment.

This study statistically showed that safety communication had a significant effect on safety commitment. The results of this study are in line with research conducted Hassan et al. (2019), which concluded that safety communication correlated with safety compliance. which was a domain of commitment.

Based on the results of research at PT. X, it is shown that the company's safety communication was still lacking, and there was no specific program regarding safety communication in the company. So far, the company has only used communication media such as posters and banners, and even then, it has not been evenly distributed across all divisions. The effect of safety communication on safety commitment in this study can be caused by good daily communication between workers and superiors. Daily communication can provide a perception of closeness between company leaders and employees. The daily verbal communication of supervisors and subordinates significantly helps increase safety, meaning that it can also build worker commitment to safety.

Daily communication in the form of safety briefings, safety talks, safety meetings, and work safety promotion media (e.g., posters, leaflets, and safety videos) can be used as a form of safety communication in the company. Integrated and routine communication efforts can also be implemented to support increased safety commitments.

\section{The Effect of Social Support on Safety Commitment}

Social support is defined as an individual's feeling valued and cared for by their social network, and how well they are attached to their social and communication network. A quite similar definition is expressed by Sarafino and Smith (2017) suggesting that social support is information or feedback from others that shows that someone is loved and cared for, valued, respected, and involved in a network of communication and reciprocal obligations. Social support for safety is the presence of other people in the work environment, either colleagues or superiors, who pay attention to safety, such as advice, reprimand, or appreciation. According to Geisler, Berthelsen and Muhonen (2019), the growth of a person's commitment can be influenced by the social support he receives while working at the company.

In this study, statistically, social support had no significant effect on safety commitment. This could happen because both workers who received low social support and workers who received high social support did not significantly differ in the distribution of safety commitment. The results of this study are aligned with the research of Geisler, Berthelsen and Muhonen (2019), which concluded that social support from superiors and coworkers was related to job satisfaction and employee commitment. The possibility that occurs is that social support is directly related without an intermediary commitment. This is in accordance with the research by Suherdin et al. (2019), which showed that social support was directly related to safety behavior.

\section{CONCLUSION}

Referring to the research objectives, based on the results of the analysis results described in the previous section, it can be concluded that management safety commitment and safety communication had a significant effect on safety commitment of workers. The low management commitment to safety caused employees to be committed to safety based on normative aspects and transactional considerations. However, workers did not have an emotional bond with company management and could describe the purpose of safety in the workplace. To increase safety commitment of workers, company management should develop OHS policies, comply with OHS standards, implement OHS, and improve safety communication. Safety communication programs need to be designed and implemented integrated with company information systems.

\section{ACKNOWLEDGEMENTS}

The researchers would like to thank the respondents, supervisors, and management of PT. $\mathrm{X}$. 


\section{REFERENCES}

Abdullah, K. H. and Aziz, F. S. A. (2021) 'Publication Trends and Thematic Evolution of 45 Years (19752020) Research on Safety Communication', Global Academic Journal of Economics and Business, 3(3), pp. 66-75.

Al-Madi, F. N. et al. (2017) 'The Impact of Employee Motivation on Organizational Commitment', European Journal of Business and Management, 9(15), pp. 134-145.

Baldissonea, G. et al. (2019) 'The Analysis and Management of Unsafe Acts and Unsafe Conditions Data Collection And Analysis', Safety Science, 119(1), pp. 240-251.

Basahel, A. M. (2021) 'Safety Leadership, Safety Attitudes, Safety Knowledge and Motivation Toward Safety-Related Behaviors in Electrical Substation Construction Projects', International Journal of Environmental Research and Public Health, 18(8), pp. 1-17.

Bird, F. . and Germain, G. . (1996) Commitment. Georgia: Institute Publishing Loganville.

Bytyqi, Q. (2020) 'Theimpact of Motivation on Organizational Commitment: an Empirical Study With Kosovar Employees', Prizren Social Science Journal, 4(3), pp. 24-32.

Chen, W. T. et al. (2018) 'The Impact of Safety Culture on Safety Performance - A Case Study of Taiwan's Constructions Industry', The International Journal of Organizational Innovation, 11(1), pp. $1-15$.

Cooper, D. (2001) Improving Safety Culture: A Practical Guide, Applied Behavioural Sciences. Available at: http://www.bsafe.co.uk (Accessed: 11 September 2019).

Fruhen, L. S., Griffin, M. A. and Andrei, D. M. (2018) 'What Does Safety Commitment Mean to Leaders? A multi-Method Investigation', Journal of Safety Research, 68(1), pp. 203-2014.

Geisler, M., Berthelsen, H. and Muhonen, T. (2019) 'Retaining Social Workers: The Role of Quality of Work andPsychosocial Safety Climate for Work Engagement, JobSatisfaction, and Organizational Commitment', Human Service Organizations: Management, Leadership \& Governance, 43(1), pp. 1-15.

Ghasemi, F. et al. (2018) 'The Role of Personal Commitment to Safety in Shaping Safety Performance of Front-Line Employees: a Case Study in Small Manufacturing Industries', Journal of Ergonomics, 6(2), pp. 16-23.
Gunasekare, U. L. T. P. (2016) 'Self Determination Theory (SDT): A Review on SDT as a Complementary Theory of Motivation', Kelaniya Journal of Human Resource Management, 11(1), pp. 58-68.

Haslinda, A. et al. (2016) 'Safety Training, Company Policy and Communication for Effective Accident Management', International Journal of Academic Research in Business and Social Sciences, 6(9), pp. 141-159.

Hassan, Z. et al. (2019) 'The Connectionbetween Safety Compliance Behaviour, Safety Communication and Safety Standardand Procedure: Aninvestigationamong Workers In Malaysian Sme's', Academy of Entrepreneurship Journal, 25(2), pp. 1-11.

Hayat, N. et al. (2020) 'Faktor Personal yang Berhubungan Dengan Komitmen Organisasi Perawat RSUD Embung Fatimah Batam', Human Care Journal, 5(3), pp. 875-882.

Jabri, B. Al and Ghazzawi, I. (2019) 'Organizational Commitment: A Review of the Conceptual and Empirical Literature and a Research Agend', International Leadership Journal, 11(1), pp. 78-119.

Lyu, S. et al. (2018) 'Relationships Among Safety Climate, Safety Behavior, and Safety Outcomes for Ethnic Minority Construction Workers', International Journal of Environmental Research and Public Health, 15(3), pp. 1-16.

Mariani, M. G., Soldà, B. L. and Curcuruto, M. (2015) 'Employee Safety Motivation: Perspectives and Measures on The Basis of The Self-Determination theory', Medicina del Lavaro, 106(5), pp. 333-341.

Mashi, M. S., Subramaniam, C. and Johari, J. (2018) 'The Effect of Management Commitment to Safety, and Safety Communication and feedback on Safety Behavior of Nurses: The Moderating Role of Consideration of Future Safety Consequences', The International Journal of Human Resource Management, 1(1), pp. 1-30.

Messner, W. (2017) 'The Role of Gender in Building Organisational Commitment in India's Services Sourcing Industry', IIMB Management Review, 29(3), pp. 188-202.

Pandit, B. et al. (2018) 'Fostering Safety Communication among Contruction Workers: Role of Safety Climate and Crew-Level Cohesion', Environmental Research and Public Health, 16(71), pp. 1-16. 
Peraturan Pemerintah Republik Indonesia (2012) Penerapan Sistem Manajemen Keselamatan dan Kesehatan Kerja. Jakarta: Presiden Republik Indonesia.

Rachmawati, D. and Paskarini, I. (2021) 'Correlation between Individual Characteristics and Rest Break with Work-Related Fatigue on Telecommunication Network Service Workers', The Indonesian Journal of Occupational Safety and Health, 10(1), pp. 25-33.

Rahman, A. V. and Dwiyanti, E. (2020) 'The Analysis of Worker Safe Behaviour based on the Antencendent Behaviour Consequence (ABC) Behaviour Model', The Indonesian Journal of Occupational Safety and Health, 9(3), pp. 309-317.

Republik Indonesia (2003) Undang-undang Nomor 20 Tahun 2003 tentang Sistem Pendidikan Nasional. Jakarta: Presiden Republik Indonesia.

Ryan, R. M. and Deci, E. L. (2002) Overview of Self Determination Theory: An OrganismicDialectical Perspective. In E. L. Deci \& R. M Ryan (Eds), Handbook of Self-Determination Reaserch. Rochester: University of Rochester Press.

Sarafino, E. . and Smith, T. W. (2017) Health Psychology: Biopsychocial Interactions. 9th Edition. New Jersey: John Wiley \& Sons Inc.

Siregar, N. A. (2020) 'Pengaruh Masa Kerja, Kepuasan Kerja dan Lingkungan Kerja terhadap Komitmen Organisasi pada PT. Lingga Tiga Sawit
Sigambal', SI-MEN (Akuntansi dan Manajemen) STIES, 11(1), pp. 30-38.

Suárez-Albanchez, J. et al. (2021) 'Occupational Health and Safety, Organisational Commitment, and Turnover Intention In The Spanish IT Consultancy Sector', International Journal of Environmental Research and Public Health, 18(11), pp. 1-13.

Suherdin et al. (2019) 'Identification of Related Factors to Safety Behavior Perception in PT. Kimia farma (Persero) Tbk. Plant Bandung', Indian Journal of Public Health Research and Development, 10(12), pp. 2012-2016.

Suherdin, Mulya, K. D. and Kurniawati, R. D. (2019) 'Dust Exposure to The Lung Function Capasity of Limestone Industry Workers in West Bandung Regency', Jurnal Ilmu Kesehatan Masyarakat, 10(2), pp. 172-183.

Sujana, I. W. C. (2019) 'Fungsi dan Tujuan Pendidikan di Indonesia', Jurnal Pendidikan Dasar, 4(1), pp. 29-39.

Umamah, A., Denny, H. M. and Kurniawan, B. (2015) 'Analisis Upaya Pencegahan dan Pengendalian Kecelakaan Kerja Pada Sebuah Pabrik Semen di Tuban', Jurnal Kesehatan Masyarakat (e-Journal), 3(3), pp. 285-295.

Yusuf, R. M. and Syarif, D. (2018) Komitmen Organisasi. Makasar: CV Nas Media Pustaka. 